\title{
Minimising the Monopoly Among Construction Players in Klang Valley, Malaysia
}

\author{
"Mashanim Mahazir, Arief Nashrin Kamarudzaman \\ Centre of Building and Resilient Development (CeBRD) \\ Faculty of Engineering, Built Environment \& IT, \\ SEGi University \\ *mashanim@segi.edu.my
}

\begin{abstract}
The rising innovations of technologies, some companies have developed greed towards owning as many projects as possible. Those involved think that they are the only ones who should be handling complex works as they are the only ones who have the right equipment to do the right job. This act of greed in the business world is known as 'monopoly'. Twenty three (23) papers were referred through extensive literature review in order to know types of monopolies, factors causing the monopoly and proposed solution to minimize monopoly among conatruction players. As a result, contractor became the most contributor to monopoly due to croinism. In order to minimize the monopoly, one should enhance the competitive advantage, embrace the sustainable development and transparency in decision making.
\end{abstract}

Keywords: Monopoly, Cronyism,

\section{Introduction}

The construction industry nowadays is rapidly expanding to keep up with the supply and demand needs for the development of a country. Over the past few years, new technologies have been discovered and implemented into the construction world to ease out the hassle of humans from going through hard work. These technologies have been proven to improve the quality of work life because with all these technologies, many 'impossible' works have been made doable. 
However, due to the rising innovations of technologies, some companies have developed greed towards owning as many projects as possible. Those involved think that they are the only ones who should be handling complex works as they are the only ones who have the right equipment to do the right job. This act of greed in the business world is known as 'monopoly'.

Monopoly, by word, means "the exclusive right of a person, corporation or state to sell a particular commodity." (Lerner, 1995). The act of monopoly has been done by several people ever since the existence of their rivals in the same job scope. The earliest modern monopoly that could be traced back is dated to be around the 1500's. "The first modern monopolies were created by the various monarchies in Europe. Figurers written by feudal lords granting land holdings and the accompanying revenues to loyal subjects during the Middle Ages became the titles and deeds that landed nobles displayed to cement their status by right of lineage.” (Beattie, 2018).

Monopoly for some types of business may be good in a way because that company is the only one that has the right resources to proceed with the job without any possible risk of failing in delivering the service. However, in construction, monopoly might not be the ideal way of a company to control the city or state's development as it may create unwanted problems that the society could not afford to bear with it.

The intended outcome of this research is to discuss on the impacts of monopoly towards the construction industry, as well as to find a solution on how to reduce the number of monopoly cases happening within the construction industry.

\section{Methodology}

Twenty three (23) papers were referred in writing extensive literature review. The analysis of findings are tabulated into table. The papers covered the types of monopolies, factors causing the monopoly and proposed solution to minimize monopoly among construction players.

\section{Result and discussion}

In the construction world, monopolies are actively happening in which it could be considered as a toxic trait for the industry's members. This is because when monopolies are happening regardless of any types, it limits the productivity of a 
company from reaching its fullest potential. Up until today, there a few types of monopolies that are happening, particularly in Malaysia, some are obvious and some are not. Those said monopolies are:

i. Monopoly by contractors.

ii. Monopoly by suppliers.

iii. Monopoly of labour workers.

These monopolies may see as if it does not affect the industry, but in reality, it actually does bring a huge impact towards the nature and the environment within the construction world. Monopolies, for some small or merging companies has been a nightmare for them as the chances for those companies to be well known as well as to build their reputation and trust have been 'blocked' by bigger companies. This is because these bigger companies are over shadowing them in terms of workability and also, the bigger companies are always the main choice for many clients to make their ideal building come to reality. But similar to the business world, monopolies may seem as an advantage for a company as people from the outside sees that company as a reliable and trusted brand, but people within the scope related to the monopolizing field sees it as a burden to the others. This is because once a company holds that monopoly 'title', many things could be affected up to the extent where it could actually affect the society of a country.

\section{A. Monopolies by contractors}

The first monopoly that is obviously happening in Malaysia is monopolies done by contractors. In other words, the same contracting company keeps receiving the major projects, or the same contracting company is dominating the construction project that could produce huge profits that benefits the government. This happens because only certain companies have the right equipment to complete the works which requires intricate and detailed observation. However, this does not mean that the companies without the advanced technology is unable to do the job, it is just that it might require longer time for them to execute the works as they are probably doing the works based on the traditional methods. Just because a company has the updated technology to keep up with the latest construction innovation, it does not mean that the said company is the only suitable company for the desired works. 
Apart from that, monopolies done by companies are also responsible for the changes of price floors for property development. Because of the same company is dominating most of the projects in an area, they have the influence to set higher prices for properties made by them. The consequence of this action is that the overall living cost of that area also needs to be in line with the property development that is happening just so to sustain any business or the area's revenue. This, in return, affects the society in many ways, mainly affecting one's financial status because they need to cope and sustain with any changes happening around them.

In relation to the changes of property value of an area, it also affects the gross domestic product of a country. Gross domestic product, by definition means that it "measures the monetary value of final goods and services - that is, those that are bought by the final user-produced in a country in a given period of time" (Callen, 2008). This means that whatever that is bought by the end-consumer affects the government's economic status. So, whenever a company or developer sets high prices for the properties in an area, the people living there has no choice but to merely accept whatever changes is happening. Moreover, based on personal experiences, within Klang Valley itself, even though the price for one unit of property has increased significantly, inflations included, but the gross floor area for one unit remains almost unchanged and this creates a slight discomfort for users, knowing that they have paid high prices for something that is not up to their expectations.

To support any points related, monopolizing companies are proven to be creating a serious cost problem that has always been overlooked. According to a journal entitled "Journal of Legal Analysis", "Because the owner has a monopoly, she will attempt to sell the property at a "monopoly price"” (Posner \& Weyl, 2017),

B. Monopolies by suppliers

Next, monopolies by suppliers in the construction is slowly happening as time goes by. What is means is that as the number of projects increases, the same supplier is being chosen to supply with all the resources needed. It may seem as if it is really not a big of a deal to project owners, but from a different perspective, it affects other suppliers from expanding its profile and being known to various parties. 
The reason why a supplier can be the preferred choice among contractors is because of its reliability in supplying the materials on a larger scale. Some suppliers may also be able to supply products which are not available within a particular country, meaning that supplier has linkages with other suppliers worldwide. This, however, can only be achieved by a supplier company if it is well established and well known for its trust and services provided, and the only way to achieve this status is by expanding the company's profile.

C. Monopolies of foreign workers

Next, monopoly of workers is also vividly happening within the Malaysian construction industry. What it means is that actually, the workforce that the companies in Malaysia are using is skewed to one type, rather than being equally distributed throughout the entire nation. The main focus of the monopoly of workers is at the labour sector, in which the labours used in Malaysia are mainly foreign labours.

On the bright side, the usage of foreign labours does have its own advantages for a company's financial status. This is because those foreign workers are willing to accept the minimum wage set up by the Malaysian government. However, from a different perspective, it affects the employment rate of locals in which the rate of unemployment is slowly increasing over time. The employment of foreign workers were originally because of the shortage of labours, as a solution, foreign workers are chosen to induce the nation's outgrowth (Yee, Abdul Rahim Abdul Hamid, \& Haziq Zul Asyraf Zahari, 2017). This, in return has affected local workers in the sense that contractors prefer to hire foreign workers for their workability and also the willingness to accept low wages (Jamadi, 2012).

Although it may seem that the impact of hiring foreign labour is not as crucial as it may sound, but actually these foreign labours have been the main driving force for all the big companies to accomplish any projects given to them. This related back to the monopoly by companies, because those companies are able to expand its profile with the resources that they managed to sustain as a result of hiring foreign workers. 
Table 1. Types of monopoly

\begin{tabular}{|c|c|c|c|c|c|c|}
\hline $\begin{array}{l}\text { Author } \\
\text { Types of } \\
\text { monopoly }\end{array}$ & $\begin{array}{c}\text { Yee, et. } \\
\text { al., } 2017\end{array}$ & $\begin{array}{l}\text { Calle } \\
\text { n, T., } \\
2008\end{array}$ & $\begin{array}{c}\text { Posner } \\
\& \\
\text { Weyl, } \\
2017\end{array}$ & $\begin{array}{l}\text { Jama } \\
\text { di, } \\
2012\end{array}$ & $\begin{array}{c}\text { Mohammad } \\
\text {, M., } 2018\end{array}$ & $\begin{array}{l}\text { Total } \\
\text { cited }\end{array}$ \\
\hline $\begin{array}{c}\text { Monopoly } \\
\text { by } \\
\text { contractors }\end{array}$ & & $\mathrm{x}$ & $\mathrm{x}$ & & & 2 \\
\hline $\begin{array}{c}\text { Monopoly } \\
\text { by } \\
\text { suppliers }\end{array}$ & & & & & $\mathrm{x}$ & 1 \\
\hline $\begin{array}{l}\text { Monopoly } \\
\text { of foreign } \\
\text { workers }\end{array}$ & $\mathrm{X}$ & & & $\mathrm{x}$ & & 2 \\
\hline
\end{tabular}

\section{Factors causing monopolies}

From the said monopolies above, there must be a factor on why those monopolies could happen. An action is said to be a monopoly when it is "as distinguished from a seller in a competitive market - arbitrarily to decide the price of the commodity, leaving it to the buyers to decide how much they will buy at that price, or, alternatively, to decide the quantity he will sell, by so fixing the price as to induce buyers to purchase just this quantity." (Lerner, 1995). This means that a company will only achieve the monopoly status when they are assumed to be influencing the price in the market, or be the only provider within that area.

\section{i. Factors causing monopolies by contractors}

The main factor why monopoly by companies may occur is because of cronyism. Cronyism is "the granting of economic favours to friends and privileged associates" (Wade, 1998). From this sentence, it clearly means that cronyism is one of the keyfactor on why monopoly may happen; it is because the employees have their own preference on who to be given the responsible for doing the works. Other than that, cronyism is also a bad habit in the construction world because not only it limits the opportunity of other companies to get projects, the attitude of cronyism will continue on as long as there are no disputes arising between the two 'agreed' parties, regardless if the person involved has the right qualification or the other way around. 
There can be two main types of cronyism happening, one being instrumental, and another one being relational (Khatri, et al., 2006). Regarding instrumental cronyism, it is mainly either by self-interest, or by tasks primarily. As for relational, it is mainly associated with relationship, and affection of one onto the other. Based on some observations and experiences, the types of cronyism which is mainly happening in Malaysia is the relational cronyism.

Apart from that, cronyism is also be also indirectly related to the lower quality of goods produced, as explained by Levine et al. (2010) because of the greed of projects and also profits. In general, cronyism can be associated with friendships or acquaintances in which the crony who does not have to have any legit qualification is able to grab any chances offered to him, just because of the person has good connections with higher-ranked personnel.

Other than that, companies that can be considered to be at 'monopoly state' remains there is because these companies often try their best to grow larger in order to dominate a large share of the market (Said, Abu Bakar, Mohd Shafie, Abd Razak, \& Yusof, 2008). When companies are able to dominate a large share of the market, they are actually able to gain the benefits under economies of scale. This is because when a company produces more output while remaining its inputs, they are able to reduce their cost expenditures. As a result, these companies are indirectly limiting the growth of smaller or upcoming companies. A construction company's growth is measured based on the ability to expand its coverage starting from local - national international - multinational - global (Flanagan, 1990 ). As for now in Malaysia, there are only several companies which qualifies to be called a multinational company, and these companies also happens to be the dominant companies within Malaysia itself. ii. Factors causing monopolies by suppliers

Next, a factor which could possibly lead to monopolies by suppliers happening is because of small firms lack the right equipment for the development that is happening around. This is because some smaller firms have very less to no exposure for biggerscaled projects in which it limits the service to be provided that enables to be well known. 
Reliability is defined as "the ability of an item to operate under designated operating conditions for a designated period of time or number of cycles" (Mohammad, 2018). When a company has no sense of reliability, it decreases the overall performance of that company because other people will not prefer to have their goods or products made or delivered by that particular company. Reliability is also associated with the performance of the quality of the product being made. The performance of a product can be described as "the reliability or the item's ability to start or continue to operate" (Mohammad, 2018). It means that even though a company is able to supply goods upon request, but if the goods made are not up to standard, it decreases the value of reliability of that company.

Another reason on why monopolies by suppliers could happen is because of the absence of a stable supply chain by suppliers. Supply chains of supplier could also be related back to its reliability, because if there is no reliability by a company, there could not be any stable supply chain created. The absence of a stable supply chain creates various problems, mainly with the performance of a company. The most obvious problem created is the presence of risks cause by supply chain problems. "Supply-chain risks can become full-fledged supply-chain problems, causing unanticipated changes in flow due to disruptions or delays" (Chopra, Sunil, \& Sodhi, 2004). So, whenever there is a delay caused by a supplier in performing its services, it affects the whole progress of the construction progress as the resources that are allocated for each event is still not attained.

So as a result of the reliability and supply chain problems that are present within the Malaysian construction industry, only a few companies are able to cope up with the supply and demand of the resources needed to carry out the works. In the end, these companies which are able to provide such services ends up monopolizing the industry.

iii. Factors causing monopolies of foreign workers

For labour workforces, it is being monopolized by foreign workers. In Malaysia, contractors are well known to hire foreign workers rather than local as the labour workers because of its reliability in doing their jobs as given. As an example, foreign labours are willing to work on public holidays, but local workers refused to work on public holidays or overtime work without being paid. Also, local Malaysian workers 
refuses to become labour workers because they have "no interest in working in rough nature of the sector, such as on construction sites that require them to exert more physical strength than working in an office where it is not hot, but rather a nice, conditioned environment." (Mydin, Buyung, MdSani, \& Abas, 2014).

Contractors in Malaysia prefers to hire foreign workers as their hard labour is because they are willing to accept low wages despite of the workload given. Another reason why contractors like to hire foreign workers by the means of low wage acceptance is because by doing this, they could "minimize the contractors' expenditures." (Marhani, et al., 2012). Nowadays, especially in the modern and developing environment in Malaysia, people are more concern about gaining profit, rather than maintaining the quality of the product. This indirectly contributes to the problems faced in the construction world in Malaysia, which is the lower quality of goods being made is associated with the relatively lower level of productivity given by these workers. This can be due to "lack of experience and knowledge of the foreign workers" (Marhani, et al., 2012).

The impact of hiring more foreign workers into the construction sector is that the rate of unemployment of locals will increase. According to the Economics Development in 2017, "the readily available pool of cheaper low-skilled foreign workers distorts domestic factor prices, and thus discourages industrial upgrading. It makes labour relatively cheap when compared to capital, and thus weakens incentives for firms to substitute labour for technology, or for greater value adding activities from employment of higher-skilled labour" (Wei, Ang, Athreya, \& Chai, 2018). This means that the rate of unemployment of locals is actually caused by the availability of cheaper labour alternatives in order for a company to maintain its profit margin. 
Table 2. Factors causing the said monopolies

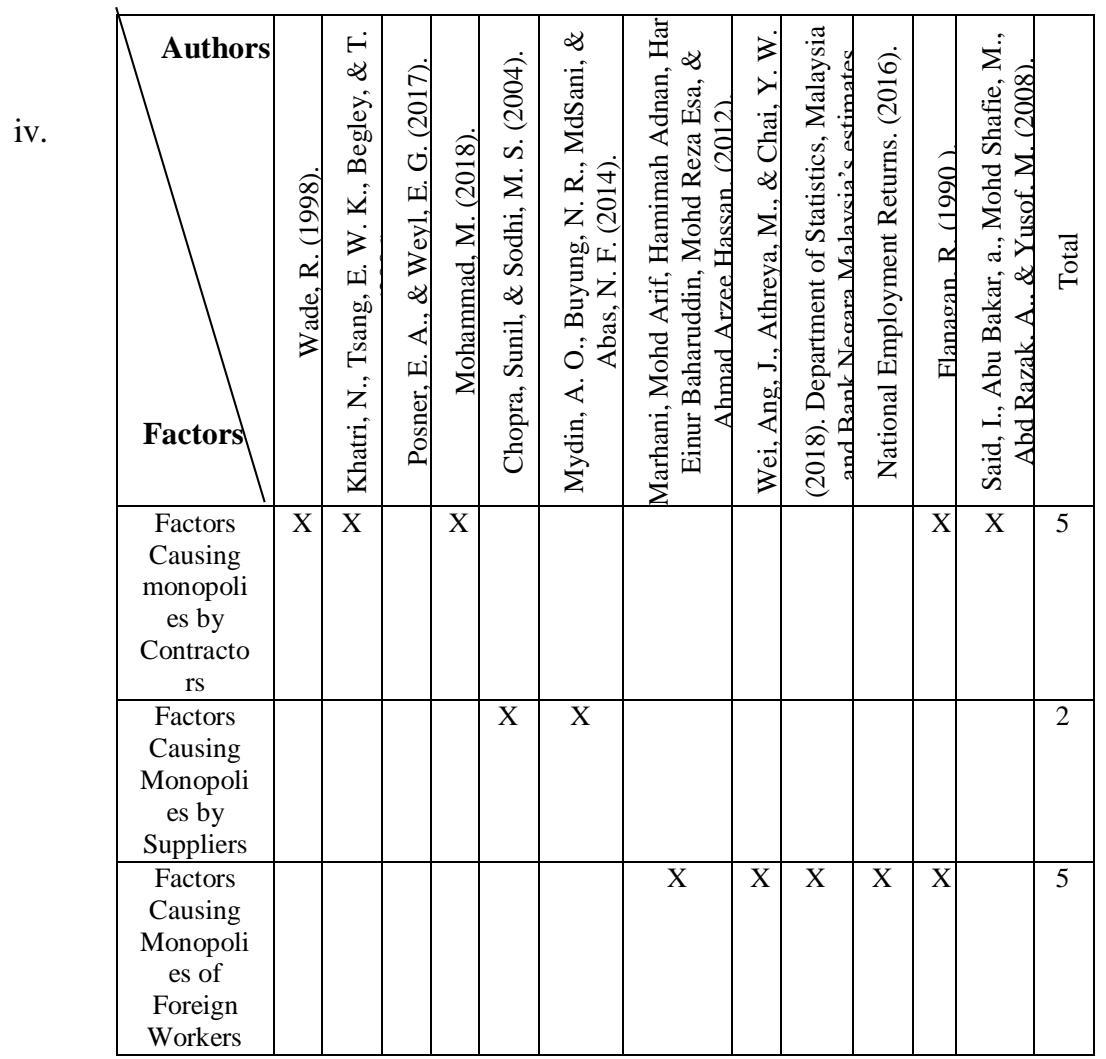

Factors and impacts due to monopoly

Based on the analysis of authors in Table 3, the percentage of monopoly caused by cronyism is the highest, followed by monopoly of labour workers. This proves that the monopoly activity that is happening is due to cronyism happening between clients and contractors.

The action of cronyism is not just limiting the growth of a company, but also tends to give an increment in status if the crony succeeds in completing the task (Zudenkova, 2011). This may indirectly also inhibit the growth of a sector because the appointment of the crony is because of the less-likeliness of competition (Zudenkova, 2011).

The second highest issue related to monopoly is the abundance of foreign workers in this sector. Moreover, labour workers are also known to be living in unsafe areas, such as within a construction compound, until the project is complete. From this, it 
shows the willingness of them to accept works without worrying the environment and also the consequences.

Another possible factor why foreign workers are more abundant in construction sectors in Malaysia is that our local workers does not like to work under extreme weathers. This may be due to the choices in workspace that local workers can choose makes them to be weighted to the non-heavy side of the works, in which they prefer to work indoors instead of outdoors.

Next, the effect of monopoly is that it tends to affect the price of a product or property. This is because when a company is dominating the area by owning many projects, users within that area have no other option but to cope with whatever that is available there. Although price inflations may also be a factor of the price increment, but it is not as significant as the price increment. Take an example of the city of Kuala Lumpur. Many of the properties there are very highly overpriced, up to the extent where the price is no longer in the area of affordable for the property being advertised, and most of the overpriced properties are constructed by big companies.

Lastly, lack of reliability may also be a cause on why monopoly is happening within the construction sector in Malaysia. This is because, as for some companies, they may not have a good record history, such as abandoned projects and low-quality workmanship. This in return results in clients having to use the same reliable company for their projects instead of giving chance for new companies to handle the projects. Also, new and emerging companies may not have a good and solid past project history, mainly because at that time, they are still not qualified to handle big projects. This results in clients to also use the companies which are already established in terms of its background, as they have proof on their workmanship and also for its ability to be responsible for such projects. 
Table 3. Issues related to monopoly

\begin{tabular}{|c|c|c|c|c|c|c|c|c|c|c|c|c|c|c|}
\hline Authors & 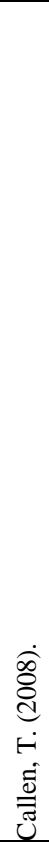 & 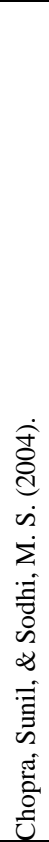 & $\begin{array}{l}\dot{\sigma} \\
\stackrel{0}{0} \\
\dot{d} \\
\dot{z} \\
\dot{E} \\
\text { 离 } \\
\dot{v}\end{array}$ & 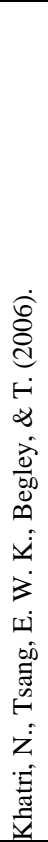 & 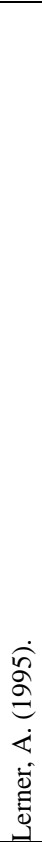 & 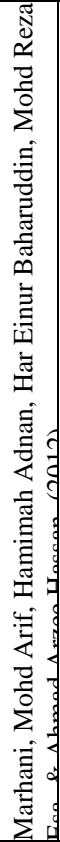 & 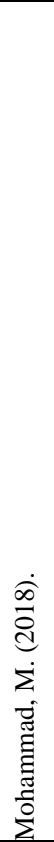 & 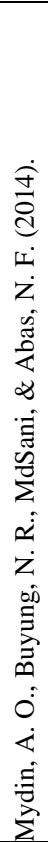 & 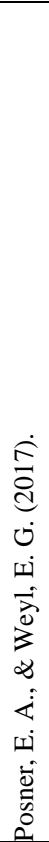 & 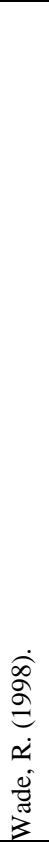 & 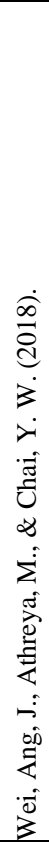 & 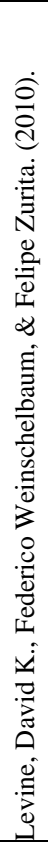 & 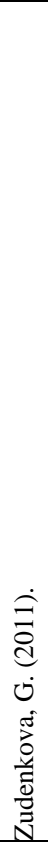 & : \\
\hline $\begin{array}{l}\text { Monopoly } \\
\text { Influences the } \\
\text { Price of a } \\
\text { Product }\end{array}$ & $\mathrm{X}$ & $\mathrm{X}$ & & & & & & & & & & & & 2 \\
\hline $\begin{array}{l}\text { Monopoly is } \\
\text { Caused by } \\
\text { Cronyism }\end{array}$ & & & & $\mathrm{X}$ & $X$ & & & & & $\mathrm{X}$ & & $\mathrm{X}$ & $X$ & 5 \\
\hline $\begin{array}{c}\text { Lack of } \\
\text { Reliability } \\
\text { Caused by } \\
\text { Cronyism } \\
\end{array}$ & & $\mathrm{X}$ & & & & & $\mathrm{X}$ & & & & & & & 2 \\
\hline $\begin{array}{c}\text { Abundance of } \\
\text { Foreign } \\
\text { Workers } \\
\text { Causes } \\
\text { Monopoly of } \\
\text { Labour } \\
\text { Workers }\end{array}$ & & & & & & $\mathrm{X}$ & & $\mathrm{X}$ & & & $\mathrm{X}$ & & & 3 \\
\hline
\end{tabular}

v. Proposed solutions to minimise monopoly from occurring within construction firms in Malaysia

Based on findings, it is safe to say that in order for a company to be and stay within the radar of being known within the construction industry, a company needs to enhance their competitive advantages for surviving and sustainable development (Ye, Lu, Ye , \& Flanagan, 2016). This is because the construction industry is based on 
demand-oriented, which means that any changes in demand within the industry will eventually affect the whole marketplace within the country. Also, by doing this, that company will now be aware of the changes that are happening and this will be a factor to keep each company in the game as so to be competitive with the other big companies.

Next, in order to reduce the number of cronyism activities happening within the construction industry is by enforcing the 'Transparency of the ties of decision makers and the organization' (Silva, Dobránszki, Al-Khatib, Bornemann-Cimenti, \& Katavić, 2019). This means that every connection that an organization has must be declared in order to avoid any hidden influence of the organization or company. It is also one of the measures to ensure that every company's background will be known by all parties. Moreover, by enforcing the transparency subject onto companies, those people involved will hopefully have the sense of responsibility to keep their company's name clean by revealing all necessary information that could be the proof that they are not at all practicing the concept of cronyism.

\section{Conclusion}

It can be concluded that, monopoly was mainly done by the contractor among the construction players. The biggest contribution to monopoly in construction is due to cronyism. In order to reduce or minimize the monopoly among the construction players, one should enhance the competitive advantage for surviving and need to embrace sustainable development. Transparencies in decision making and the organization also plays important role in minimizing the monopoly. The summary is depicted in Figure 1.

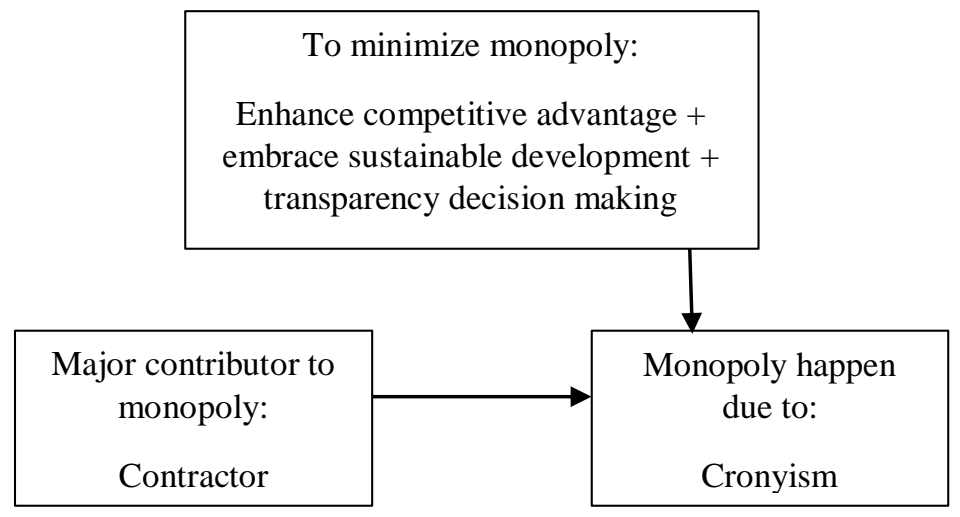


Figure 1. Contributor to cronyism and way to minimise monopoly among construction player.

\section{Acknowledgement}

The authors would like to thank SEGi University for the opportunity and platform provided.

\section{References}

Beattie, A. (2018, January 5). Early Monopolies: Conquest and Corruption.

Callen, T. (2008). What is gross domestic product. Finance and Development, 45(4), 48-49.

Chopra, Sunil, \& Sodhi, M. S. (2004). Supply chain breakdown. MIT Sloan management review 46(1), 53-61.

Flanagan, R. (1990). Making International Comparisons In The Global Construction Market. CIB 90, vol 5, 230-246.

Jamadi, M. A. (2012). Foreign labour employment in construction project. Retrieved from: Universiti Teknologi Malaysia Institutional Repository.

Khatri, N. (2016). Definitions of cronyism, corruption, and crony capitalism. London: Palgrave Macmillan.

Khatri, N., Tsang, E. W. K., Begley, \& T. (2006). Cronyism: A cross-cultural analysis. Journal of International Business Studies, 37(1), 61-75.

Lerner, A. (1995). the concept of monopoly and the measurement of monopoly power. In Essential readings in economics (pp. 55-76). London: Palgrave.

Marhani, Mohd Arif, Hamimah Adnan, Har Einur Baharuddin, Mohd Reza Esa, \& Ahmad Arzee Hassan. (2012). Dependency of foreign workers in Malaysian construction industry. Built Environment journal 9(1), 39-50.

Mohammad, M. (2018). What every engineer should know about reliability and risk analysis. CRC Press.

Mydin, A. O., Buyung, N. R., MdSani, \& Abas, N. F. (2014). Trends and Reliance on Foreign Labourers in Malaysia:. SHS Web of Conferences vol.11, 1004.

Posner, E. A., \& Weyl, E. G. (2017). Property Is Only Another Name for Monopoly. Journal of Legal Analysis, Volume 9, Issue 1,, 51-123.

Said, I., Abu Bakar, a., Mohd Shafie, M., Abd Razak, A., \& Yusof, M. (2008). GROWTH Factors For Construction Companies In Malaysia. 2nd International Conference On Built Environment In Developing Countries (ICBEDC 2008), (pp. 1296-1310).

Silva, J. T., Dobránszki, J., Al-Khatib, A., Bornemann-Cimenti, H., \& Katavić, V. (2019). Establishing Rules for Ethicists and Ethics Organizations in Academic Publishing to Avoid Conflicts of Interest, Favoritism, Cronyism and Nepotism. Journal of Pure Communication Inquiry (DOI: 10.17646). 
Wade, R. (1998). From 'miracle' to 'cronyism': explaining the Great Asian Slump. Cambridge journal of economics 22(6), 693-706.

Wei, Ang, J., Athreya, M., \& Chai, Y. W. (2018). Low-skilled Foreign Workers' Distortions to the Economy.

Yee, M., Lu, W., Ye , K., \& Flanagan, R. (2016). How Do Top Construction Companies Diversify in the International Construction Market? Proceedings of the 20th International Symposium on Advancement of Construction Management and Real Estate (pp. 101-110). Springer Singapore.

Yee, K. C., Abdul Rahim Abdul Hamid , \& Haziq Zul Asyraf Zahari. (2017). Foreign workers' composition at construction site. Journal of Advanced Research Design 30 , Issue 1, 12-21.

Zudenkova, G. (2011). Cronyism in Business, Public Sector and Politics. Retrieved from http://mpra.ub.uni-muenchen.de/30231. 